\title{
ANALISIS RASIO LIKUIDITAS DAN PROFITABILITAS LAPORAN KEUANGAN KOPERASI SEKOLAH TINGKAT SEKOLAH LANJUTAN TINGKAT ATAS (SLTA) DI KOTA PALEMBANG
}

\author{
Oleh: Zahruddin Hodsay ${ }^{1}$, Fitria Nurjanah, Nur'aini, Dika Pransiska, \\ Loverince Clarra Meilynda, Satria Andika \\ (UNIVERSITAS PGRI PALEMBANG) \\ ${ }^{1)}$ zhodsay@gmail.com
}

\begin{abstract}
Abstrak
Penelitian ini berjudul Analisis Rasio Likuiditas dan Profitabilitas Laporan Keuangan Koperasi Sekolah Tingkat Sekolah Lanjutan Tingkat Atas (SLTA) di kota Palembang. Tujuan dari penelitian ini adalah untuk mengetahui kinerja keuangan yang diukur dengan rasio likuiditas dan profitabilitas atas laporan keuangan koperasi sekolah tingkat SLTA di kota Palembang. Objek dalam penelitian ini adalah laporan keuangan tahun 2014, 2015 dan 2016 dari koperasi sekolah SMAN 19 Palembang, SMA Muhammadiyan 1 Palembang, SMKN 1 Palembang, SMK PGRI 1 Palembang dan MAN 1 Palembang. Penelitian ini menggunakan metode penelitian deskriptif kualitatif. Adapun teknik pengumpulan data dalam penelitian ini adalah dokumentasi, kajian pustaka dan wawancara. Sedangkan teknik analisis data dengan menggunakan rumus rasio-rasio laporan keuangan. Hasil penelitian menunjukkan bahwa rata-rata rasio lancar pada koperasi tingkat SLTA di kota Palembang tahun 2014 sebesar 41,9, tahun 2015 sebesar 45,1, dan tahun 2016 sebesar 51,9. Demikian juga untuk tahun 2015 dan 2016, utang lancar lebih besar lagi dapat dijamin oleh aktiva lancar koperasi sekolah. Margin laba (profit margin) tahun 2014 rata-rata sebesar 61,1\%, tahun 2015 rata-rata sebesar 72,9\%, dan tahun 2016 rata-rata sebesar 65,7\%. Dapat disimpulkan bahwa rasio lancar dan margin laba (profit margin) pada koperasi sekolah tingkat SLTA di Kota Palembang dari tiga tahun terakhir dikategorikan sehat.
\end{abstract}

Kata Kunci : Likuditas, Profitabilitas, Laporan Keuangan, Koperasi Sekolah

\section{ANAL YSIS OF LIQUIDITY RATIO AND PROFITABILITY FINANCIAL REPORT OF SCHOOL COOPERATION AT THE SENIOR HIGH SCHOOL OF PALEMBANG}

\begin{abstract}
This research entitled the analysis of liquidity ratios and profitability and financial statements of school cooperatives at the Senior high school of Palembang. The purpose of this study is to determine the financial performance by the ratio of liquidity and profitability of financial statements of school cooperatives at the senior high school of Palembang. Objects this study are the financial reports of 2014, 2015 and 2016 from cooperative school at Senior High
\end{abstract}


school 19 of Palembang, Senior High School Muhammadiyah 1 of Palembang, Vocational High School 1 of palembang, Vocational High School PGRI 1 of Palembang and Islamic High School 1 of Palembang. This research uses qualitative descriptive research method. For collection techniques data in this research are documentation, literature review and interviews. The technique of analysis data uses the formula of the ratio of financial reports. The results showed that the average current ratio of school co-operatives of Palembang in 2014 by to 41.9, in 2015 by 45.1 and 2016 of 51.9. In 2015 and 2016, more current debt can be secured by current assets of school cooperatives. In 2014 profit margin averaged $61.1 \%$, in 2015 an average of $72.9 \%$ and 2016 average $65.7 \%$. The concluded that the current ratio and profit margin of school co-operatives in Palembang three years are categorized is good.

Keywords : Liquidity, Profitability, Financial Report, School Cooperation

\section{PENDAHULUAN}

Keberhasilan dalam mencapai laba merupakan prestasi manajemen suatu lembaga atau perusahaan, demikian juga halnya dengan koperasi. Penilaian prestasi dapat diukur karena dapat dipakai sebagai dasar pengambilan keputusan, baik untuk kepentingan pihak internal maupun eksternal. Kinerja keuangan adalah suatu gambaran kondisi keuangan yang dianalisis dengan alat-alat analisis keuangan, sehingga dapat diketahui perkembangan dan kemajuan keuangan pada periode tertentu. Salah satu cara untuk mengetahuinya dengan cara menganalisis hubungan dari berbagai pos dalam suatu laporan keuangan. Laporan keuangan adalah laporan yang menunjukkan kondisi keuangan perusahaan pada saat ini atau dalam suatu periode tertentu (Kasmir, 2015:7). Laporan keuangan pada prinsipnya merupakan hasil dari suatu proses akuntansi yang dapat digunakan sebagai alat untuk memberi informasi mengenai data keuangan.

Secara umum orang mengetahui bahwa koperasi adalah sebagai suatu perkumpulan yang didirikan oleh orang-orang yang memiliki kemampuan ekonomi terbatas, yaitu bertujuan untuk memperjuangkan peningkatan kesejahteraan ekonomi anggotanya. Dasar hukum keberadaan koperasi di Indonesia adalah pasal 33 UUD Tahun 1945 dan UU Nomor 25 tahun 
1992 tentang Perkoperasian. Pada poin penjelasan pasal 33 ayat (1) UUD tahun 1945 antara lain dikemukakan bahwa perekonomian disusun sebagai usaha bersama berdasar atas asas kekeluargaan dan ayat (4) dikemukakan bahwa perekonomian nasional diselenggarakan berdasar atas demokrasi ekonomi dengan prinsip kebersamaan, efisiensi, berkeadilan, berkelanjutan, berwawasan lingkungan, kemandirian, serta dengan menjaga keseimbangan. Sedangkan menurut pasal $1 \mathrm{UU}$ No.25 tahun 1992 tentang Perkoperasian yang dimaksud dengan koperasi adalah badan usaha yang beranggotakan orang-seseorang atau badan hukum koperasi dengan melandaskan kegiatan berdasarkan atas asas kekeluargaan.

Pendirian koperasi sekolah didasarkan pada Surat Keputusan bersama antara Departemen Transmigrasi dan Koperasi dengan Departemen Pendidikan dan Kebudayaan Tanggal 16 Juli 1972 Nomor 275/KPTS/Mentranskop dan Nomor 0102/U/1983. Selanjutnya dijelaskan lebih lanjut dalam Surat
Keputusan Menteri Tenaga Kerja, Transmigrasi, dan Koperasi Nomor 633/SKPTS/Men/1974 yang dimaksud dengan koperasi sekolah adalah koperasi yang didirikan di sekolah-sekolah SD, SMP, SMA, madrasah dan pesantren.

Koperasi sekolah merupakan koperasi yang dibentuk di sekolah. Pendiriannya diharapkan mampu menjadi sebuah sarana bagi siswasiswi untuk belajar melakukan bisnis kecil, mengembangkan keterampilan organisasi, serta mendorong kebiasaan dalam usaha gotongroyong. Koperasi sekolah beranggotakan siswa dan warga sekolah. Tujuan dari pendirian koperasi ini yaitu untuk memajukan kesejahteraan anggota dan masyarakat serta membangun tatanan perekonomian nasional. Oleh karena itu perlu sekali koperasi jenis ini untuk didirikan karena dengan adanya koperasi dapat menanamkan rasa gotong royong kepada warga sekolah yaitu siswa dan guru-guru sehingga tujuan pengembangan koperasi di Indonesia dapat terwujud.

Untuk mengetahui kondisi keuangan koperasi pada suatau 
periode tertentu merupakan hal yang penting. Mengingat hal tersebut dapat digunakan untuk mengetahui kondisi keuangan koperasi, pengurus dapat mengukur tingkat keberhasilan koperasi dan dapat menentukan kebijakan apa yang cocok untuk digunakan demi tercapainya tujuan koperasi yaitu meningkatkan kesejahteraan anggota. Tidak semua koperasi sekolah tingkat SLTA di kota Palembang melakukan analisis laporan keuangan dan perhitungan ratio. Seyogyanya koperasi pelajar sekolah tingkat SLTA di kota Palembang juga perlu mengadakan analisis laporan keuangannya untuk mengetahui kondisi keuangan pada saat tertentu

Beranjak dari pemikiran dan permasalahan di atas, maka peneliti tertarik untuk mengadakan penelitian pada koperasi sekolah tingkat SLTA di kota Palembang dengan judul "Analisis Rasio Likuiditas dan Profitabilitas Laporan Keuangan Koperasi Sekolah Tingkat Sekolah Lanjutan Tingkat Atas (SLTA) di Kota Palembang".

Untuk menghindari agar penelitian ini tidak menyimpang maka perlu diadakan pembatasan ruang lingkup permasalahan yaitu : Objek penelitian ini adalah laporan keuangan koperasi sekolah tingkat SLTA di kota Palembang yaitu SMAN 19 Palembang, SMA Muhammadiyan 1 Palembang, SMKN 1 Palembang, SMK PGRI 1 Palembang dan MAN 1 Palembang. Laporan keuangan yang diteliti adalah tahun 2014, 2015, dan 2016. Rasio yang diteliti adalah rasio likuiditas dan rasio profitabilitas/rasio rentabilitas. Berdasarkan uraian latar belakang di atas, maka rumusan masalah dalam penelitian ini yaitu bagaimanakah Rasio Likuiditas dan Profitabilitas Laporan Keuangan Koperasi Sekolah Tingkat Sekolah Lanjutan Tingkat Atas (SLTA) di Kota Palembang?

Tujuan dari penelitian ini adalah untuk mengetahui kinerja keuangan yang diukur dengan rasio laporan keuangan (likuiditas dan profitabilitas) koperasi sekolah tingkat Sekolah Lanjutan Tingkat Atas (SLTA) di Kota Palembang. Penelitian ini diharapkan dapat bermanfaat bagi semua pihak yaitu bagi koperasi sekolah tingkat SLTA 
di kota Palembang, sebagai acuan dan pedoman koperasi serta sebagai bahan masukan dalam mengelola keuangannya di masa yang akan datang, bagi sekolah dengan diadakannya penelitian ini maka diharapkan pihak-pihak sekolah dapat lebih memperhatikan kemajuan keuangan koperasi pelajar, bagi anggota koperasi sebagai bahan pertimbangan dalam memberikan kontribusi aktif dalam memajukan koperasi dan bagi perguruan tinggi untuk menambah pengetahuan, informasi dan bahan acuan untuk referensi dalam penelitian yang serupa yang menggunakan laporan keuangan koperasi.

\section{LANDASAN TEORI}

\section{a. Pengertian Rasio}

Horne dalam Kasmir (2010 : 104) mengatakan bahwa rasio keuangan merupakan indeks yang menghubungkan dua angka akuntansi dan diperoleh dengan membagi suatu angka dengan angka lainnya. Sedangakan menurut Munawir (2012 : 64) bahwa rasio menggambarkan suatu hubungan atau perimbangan antara suatu jumlah tertentu dengan jumlah yang lain, dan dengan menggunakan alat analisa berupa rasio ini akan dapat menjelaskan atau memberi gambaran kepada penganalisa tentang baik buruknya keadaan posisi keuangan suatu perusahaan terutama apabila angka rasio tersebut dibandingkan dengan angka rasio perbandingan yang digunakan sebagai standar. Pendapat lainnya bahwa rasio keuangan adalah angka yang diperoleh dari hasil perbandingan dari satu pos laporan keuangan dengan pos lainnya yang mempunyai hubungan yang relevan dan signifikan (Harahap, 2010 : 297).

$$
\text { Berdasarkan }
$$

beberapa pendapat di atas dapat disimpulkan bahwa rasio keuangan adalah angka yang digunakan untuk mengevaluasi kondisi keuangan dan kinerja suatu perusahaan yang diperoleh dari hasil perbandingan dari satu pos laporan keuangan dengan pos lainnya yang mempunyai hubungan yang relevan dan signifikan.

\section{b. Pengelompokkan Angka Rasio \\ Pada praktiknya Kasmir (2015 : 105) membagi rasio}


keuangan suatu perusahaan ke dalam beberapa golongan, yaitu ::

a. Rasio neraca, yaitu membandingkan angka-angka yang hanya bersumber dari neraca.

b. Rasio laporan laba rugi, yaitu membandingkan angka-angka yang hanya bersumber dari laporan laba rugi.

c. Rasio antarlaporan, yaitu membandingkan angka-angka dari dua sumber (data campuran), baik yang ada di neraca maupun di laporan laba rugi.

\section{c. Jenis Rasio}

Menurut Courties dalam Harahap (2010 : 299) perlu memperhatikan adanya tiga aspek penting dalam menganalisis laporan keuangan, antara lain :

a. Profitabilitas. Kemampuan perusahaan menghasilkan laba yang digambarkan oleh Return On Investment (ROI).

b. Management Performance adalah rasio yang dapat menilai prestasi manajemen. Ia melihat dari segi kebijakan kredit, persediaan, administrasi, dan struktur harta dan modal.

c. Solvency, kemampuan perusahaan melunasi kewajibannya. Solvency ini digambarkan oleh arus kas baik jangka pendek maupun jangka panjang.

Namun di lain pihak ada juga rasio keuangan yang sering digunakan, menurut Harahap (2010 : 301-311) rasio keuangan yaitu sebagai berikut: Rasio Likuiditas; Rasio Solvabilitas; Rasio Profitabilitas/Rentabilitas; Rasio Leverage; Rasio Aktivitas; Rasio Pertumbuhan; Market Based (Penilaian Pasar); dan Rasio Produktivitas.

Rasio likuiditas adalah kemampuan perusahaan untuk menyelesaikan kewajiban jangka pendeknya. Rasio-rasio ini dapat dihitung melalui sumber informasi tentang modal kerja yaitu pos-pos aktiva lancar dan utang lancar. Sedangakan rasio solvabilitas adalah kemampuan perusahaan dalam membayar kewajiban jangka panjangnya atau kewajibankewajibannya apabila perusahaan 
dilikuidasi. Selanjutnya rasio rentabilitas atau disebut juga profitabilitas adalah kemampuan perusahaan mendapatkan laba melalui semua kemampuan, dan sumber yang ada seperti kegiatan penjualan, kas, modal, jumlah karyawan, jumlah cabang dan sebagainya. Rasio yang menggambarkan kemmapuan perusahaan menghasilkan laba disebut juga operating ratio. Kemudian rasio aktivitas adalah aktivitas yang dilakukan perusahaan dalam menjalankan operasinya baik dalam kegiatan penjualan, pembelian dan kegiatan lainnya. Terakhir rasio pertumbuhan adalah persentasi pertumbuhan pos-pos perusahaan dari tahun ke tahun. Sedangkan rasio produktivitasi menunjukkan tingkat produktivitas dari unit atau kegiatan yang dinilai.

\section{d. Pengertian Laporan Keuangan}

Munawir (2012 : 2)
mengungkapkan bahwa laporan
keuangan adalah hasil dari proses
akuntansi yang dapat digunakan
sebagai alat untuk berkomunikasi
antara data keuangan atau aktivitas

suatu perusahaan dengan pihak-pihak yang berkepentingan dengan data atau aktivitas perusahaan tersebut. Pendapat serupa dari Sugiri dan Riyono (2008:21) berpendapat laporan keuangan merupakan hasil akhir dari suatu siklus skuntansi. Sedangkan menurut Harahap (2010:105) berpendapat bahwa laporan keuangan menggambarkan kondisi keuangan dan hasil usaha suatu perusahaan pada saat tertentu atau jangka waktu tertentu.

Berdasar beberapa pendapat di atas dapat disimpulkan laporan keuangan adalah catatan informasi keuangan yang disusun rapi oleh perusahaan untuk mengevaluasi kinerja keuangannya dalam periode tertentu, yang berguna untuk memenuhi pihak-pihak yang memakainya atau yang berkepentingan.

\section{e. Jenis-Jenis Laporan Keuangan}

Menurut Kasmir (2015：7) dikenal beberapa macam laporan keuangan yaitu :

1) Neraca

Neraca merupakan laporan yang menunjukkan jumlah aktiva 
(harta), kewajiban (utang), dan modal (ekuitas) perusahaan pada saat tertentu.

2) Laporan Laba Rugi

Laporan laba rugi menunjukkan kondisi usaha dalam suatu periode tertentu. Artinya laporan laba rugi harus dibuat dalam suatu siklus periode tertentu guna mengetahui jumlah perolehan pendapatan dan biaya yang telah dikeluarkan.

3) Laporan Perubahan Modal Laporan perubahan modal menggambarkan jumlah modal yang dimiliki perusahaan saat ini. Kemudian, laporan ini juga menunjukkan perubahan modal serta sebab-sebab berubahnya modal.

4) Laporan Catatan atas Laporan Keuangan

Laporan catatan atas laporan keuangan merupakan laporan yang dibuat berkaitan dengan laporan keuangan yang disajikan.

5) Laporan Arus Kas

Laporan arus kas merupakan laporan yang menunjukkan arus kas masuk dan arus kas keluar di perusahaan. Arus kas masuk berupa pendapatan atau pinjaman dari pihak lain, sedangkan arus kas keluar merupakan biaya-biaya yang telah dikeluarkan perusahaan.

\section{f. Pengertian Koperasi Sekolah}

Koperasi sekolah adalah koperasi yang didirikan dilingkungan sekolah yang beranggotakan muridmurid, yang didirikan diberbagai sekolah sesuai tingkatan atau jenjang pendidikan (Westriningsih, 2008 : 11). Selanjutnya menurut Ali dalam Murtika (2004 : 183) koperasi sekolah adalah koperasi yang ada di lingkungan sekolah, akan tetapi pengelolaanya dilakukan oleh siswa.

Landasan didirikannya koperasi sekolah adalah keputusan bersama antara departemen transmigrasi dan koperasi dengan pendidikan dan kebudayaan tanggal 16 Juli 1972 Nomor 275/SKPT/Mentranskop dan Nomor 633/KPTS/Men/1974 menjelaskan bahwa koperasi sekolah adalah koperasi yang didirikan di Sekolah Dasar, Sekolah Menengah Pertama, 
Sekolah Menengah Atas/Kejuruan, Madrasah dan Pesantren.

Berdasar pengertianpengertian dari koperasi sekolah di atas maka dapat disimpulkan bahwa koperasi sekolah adalah koperasi yang didirikan di lingkungan sekolah yang anggotanya terdiri atas siswasiswi sekolah. Melalui koperasi sekolah inilah para peserta didik dapat saling bersosialisasi dengan anggota lain, serta dapat memenuhi kebutuhan yang diusahakan secara bersama dan dikelola secara bersama untuk kesejahteraan bersama.।

\section{g. Ciri-Ciri Koperasi Sekolah}

Ciri-ciri koperasi sekolah menurut undang-undang Nomor 17 Tahun 2012 adalah sebagai berikut:

a. Koperasi sekolah didirikan dalam rangka kegiatan belajar para siswa.

b. Anggotanya adalah kalangan siswa sekolah yang bersangkutan.

c. Tidak disyaratkan berbadan hukum.

d. Berfungsi sebagai laboratorium pengajaran koperasi sekolah.
Sedangkan

menurut

Westriningsih (2008 : 13), ciri khas koperasi sekolah adalah sebagai berikut:

1. Didirikan atas surat keputusan bekerja sama antar departemen.

2. Tidak berbadan hukum, tetapi diakui oleh menteri Negara koperasi dan usaha kecil menengah sebagai koperasi.

3. Anggotanya terdiri atas murid atau pelajar.

4. Jangka waktu keanggotaan terbatas. Artinya, selama masih menjadi murid di sekolahmu sekarang, berarti masih menjadi anggota koperasi sekolahmu. Akan tetapi, jika kamu lulus atau pindah ke sekolah lain keanggotaanmu di koperasi lama akan berakhir.

\section{h. Tujuan Koperasi Sekolah}

Menurut Westriningsuh (2008 : 13) tujuan koperasi sekolah sebenarnya hampir sama dengan tujuan koperasi pada umumnya. Tujuan koperasi sekolah secara lengkap adalah: 
1) Menanamkan jiwa gotong

9) Sarana untuk memenuhi royong dan setia kawan di antara kebutuhan sekolah siswa, siswa. misalnya buku, alat tulis, dan

2) Memupuk rasa cinta pada makanan kecil. sekolah.

10) Pembagian sisa hasil usaha

3) Kemauan usaha bagi siswa.

4) Meningkatkan pengetahuan dan keterampilan siswa. (SHU) yang dapat digunakan sebagai uang tambahan menanamkan sikap hidup hemat.

5) Menanamkan hubungan baik antara siswa, guru, dan anggota sekolah yang lain.

i. Standar Pengukuran Rasio Keuangan Koperasi

6) Menjaga hubungan baik antara siswa, guru, dan anggota sekolah.

7) Mendukung pendidikan sekolah pada kegiatan yang bermanfaat.

8) Mengembangkan jiwa demokratis.

Berdasarkan Peraturan Menteri Negara Koperasi dan UKM Republik Indonesia Nomor 06/Per/M.KUKM/V/2006 tanggal 1 Mei 2006 tentang pedoman penilaian koperasi berprestasi/koperasi award dapat dilihat seperti tabel berikut : 
TABEL 1

KRITERIA STANDAR PENILAIAN KOPERASI BERPRESTASI

\begin{tabular}{|c|c|c|c|}
\hline No. & Jenis Rasio & Standar Rasio & Kriteria \\
\hline \multirow[t]{6}{*}{1.} & Rasio Likuiditas & & \\
\hline & Rasio Lancar (current ratio) & $200 \% \mathrm{~s} / \mathrm{d} 250 \%$ & Sehat \\
\hline & & $175 \%-200 \%$ & Cukup Sehat \\
\hline & & $150 \%-175 \%$ & Kurang Sehat \\
\hline & & $125 \%-150 \%$ & Tidak Sehat \\
\hline & & $<125 \%$ & Sangat Tidak Sehat \\
\hline \multirow[t]{21}{*}{2.} & Rasio Profitabilitas & & \\
\hline & Net Profit Margin & $\geq 15 \%$ & Sehat \\
\hline & & $10 \%-<15 \%$ & Cukup Sehat \\
\hline & & $5 \%-<10 \%$ & Kurang Sehat \\
\hline & & $1 \%-<5 \%$ & Tidak Sehat \\
\hline & & $<1 \%$ & Sangat Tidak Sehat \\
\hline & Return On Asset & $\geq 10 \%$ & Sehat \\
\hline & & $7 \%-<10 \%$ & Cukup Sehat \\
\hline & & $3 \%-<7 \%$ & Kurang Sehat \\
\hline & & $1 \%-<3 \%$ & Tidak Sehat \\
\hline & & $<1 \%$ & Sangat Tidak Sehat \\
\hline & Asset Turn Over & $\geq 3,5$ kali & Sehat \\
\hline & & 2,5 kali $-<3,5$ kali & Cukup Sehat \\
\hline & & 1,5 kali $-<2,5$ kali & Kurang Sehat \\
\hline & & 1 kali $-<1,5$ kali & Tidak Sehat \\
\hline & & $<1$ kali & Sangat Tidak Sehat \\
\hline & Rentabilitas Modal Sendiri & $\geq 21 \%$ & Sehat \\
\hline & & $15 \%-<21 \%$ & Cukup Sehat \\
\hline & & $9 \%-<15 \%$ & Kurang Sehat \\
\hline & & $3 \%-<9 \%$ & Tidak Sehat \\
\hline & & $<3 \%$ & Sangat Tidak Sehat \\
\hline
\end{tabular}

Sumber data : (Peraturan Menteri Negara Koperasi dan UKM Republik Indonesia Nomor 06/Per/M.KUKM/V/2006)

\section{METODE PENELITIAN}

\section{a. Objek Penelitian}

Sugiyono (2012: $\quad 38)$

menyampaikan bahwa objek penelitian adalah suatu atribut atau sifat atau nilai dari orang. Objek penelitian adalah apa yang menjadi titik perhatian suatu penelitian (Arikunto, 2010 : 15). Dengan mengacu pada pengertian tersebut, maka yang menjadi objek dalam penelitian ini adalah laporan keuangan tahun 2014, 2015 dan 2016 pada Koperasi Sekolah di SMAN 19 
Palembang, SMA Muhammadiyan 1 Palembang, SMKN 1 Palembang, SMK PGRI 1 Palembang dan MAN 1 Palembang. Penelitian ini adalah penelitian bersama antara dosen dan mahasiswa yang sedang mengerjakan dan menyelesaikan penelitian (skripsi) dengan objek penelitian yang sama yaitu koperasi sekolah.

\section{b. Metode Penelitian}

Sugiyono (2016 : 3) berpendapat "metode penelitian merupakan sebagai cara ilmiah untuk mendapatkan data dengan tujuan tertentu dan kegunaan tertentu". Sedangkan menurut Arikunto (2013 : 19) "metode deskriptif adalah metode yang digunakan untuk menggambarkan atau menganalisis suatu hasil penelitian tetapi tidak digunakan untuk membuat kesimpulan yang lebih luas”.

Berdasarkan pengertian di atas dapat disimpulkan metode deskriptif dengan pendekatan kualitatif digunakan dimaksud untuk membuat deskripsi, gambaran secara sistematis, faktual, dan akurat mengenai suatu objek pada kondisi masa sekarang serta hubungan antar kejadian yang diselidiki.

\section{c. Teknik Pengumpulan Data}

Adapun teknik pengumpulan data dalam penelitian ini adalah :

1. Dokumentasi

Berdasarkan pendapat Sugiyono (2016 : 240), dokumen merupakan catatan yang sudah berlalu. Dokumen bias berbentuk tulisan, gambar, atau karya-karya menu mental dari seorang. Dokumen bisa berbentuk tulisan, gambar, atau karya-karya monumental dari seseorang. Teknik ini digunakan untuk mengetahui Neraca, Sisa Hasil Usaha (SHU), jumlah piutang, jumlah anggota, dan buku-buku yang digunakan.

\section{Wawancara}

Menurut Sugiyono (2010 : 194) "wawancara digunakan sebagai teknik pengumpulan data apabila peneliti ingin melakukan studi pendahuluan untuk menemukan permasalahan yang diteliti”. Wawancara digunakan untuk mengetahui pengelolaan koperasi, peluang-peluang dan hambatanhambatan dalam koperasi dan 
klarifikasi dari hasil perhitungan rasio-rasio laporan keuangan yang ada di koperasi. Wawancara ini dilakukan kepada ketua koperasi serta pengelola koperasi.

\section{d. Teknik Analisis Data}

Menyangkut teknis analisdata, Sugiyono (2016 : 244) mengatakan bahwa teknik analisis data adalah proses mencari dan menyusun secara sistematis data dengan cara mengorganisasikan data kedalam kategori, menjabarkan kedalam unit-unit, melakukan sintesa, menyusun kedalam pola, memilih mana yang penting dan yang akan dipelajari, dan membuat kesimpulan sehingga mudah dipahami oleh diri sendiri maupun orang lain.

Teknis analisis data yang digunakan dalam penelitian ini adalah dengan perhitungan rasio sebagaimana menurut Harahap (2010 : 301-311) antara lain :

\section{Rasio Likuiditas}
a. Rasio Lancar $=\frac{\text { Aktiva Lancar }}{\text { Utang Lancar }}$
b. Rasio Cepat = Aktiva Lancar - Persediaan Utang Lancar

c. Rasio Kas atas Aktiva Lancar

$$
=\frac{\text { Kas }}{\text { Aktiva Lancar }}
$$

d. Rasio Kas atas Utang Lancar

$$
=\frac{\text { Kas }}{\text { Utang Lancar }}
$$

e. Rasio Aktiva Lancar dan Total

$$
\text { Aktiva }=\frac{\text { Aktiva Lancar }}{\text { Total Aktiva }}
$$

\section{Rasio Rentabilitas/Profitabilitas}

a. Margin Laba (Profit Margin)

$$
=\frac{\text { Pendapatan Bersih }}{\text { Penjualan }}
$$

b. Aset Turn Over (Return On Aset

$$
\text { ) }=\frac{\text { Penjualan Bersih }}{\text { Total Aktiva }}
$$

c. Return on Investment =

$$
\frac{\text { Laba Bersih }}{\text { Rata -rata Modal }}
$$

d. Return on Total Aset =

$$
\frac{\text { Laba Bersih }}{\text { Rata -rata Total Aset }}
$$

\section{HASIL PENELITIAN DAN PEMBAHASAN}

Berdasarkan data-data laporan keuangan telah diperoleh antara lain Laporan Sisa Hasil Usaha (SHU) dan Neraca dari 5 koperasi sekolah yang diteliti, maka dapat dihitung setiap rasio laporan keuangan selama 3 tahun yaitu tahun 2014, 2015 dan 2016. Sebagaimana disebutkan sebelumnya, 5 koperasi sekolah 
dimaksud adalah koperasi sekolah SMAN 19 Palembang, SMA Muhammadiyan 1 Palembang, SMKN 1 Palembang, SMK PGRI 1 Palembang dan MAN 1 Palembang.
Berikut hasil penelitian dan pembahasan dari penelitian ini :

\section{Rasio Likuiditas}

a. Rasio Lancar

TABEL 1 RASIO LANCAR LAPORAN KEUANGAN KOPERASI SEKOLAH

\begin{tabular}{|l|l|r|r|r|}
\hline No & \multicolumn{1}{|c|}{ Nama Sekolah } & Tahun 2014 & Tahun 2015 & Tahun 2016 \\
\hline 1. & SMA Negeri 19 Palembang & 100,9 & 82,5 & 98,5 \\
\hline 2. & SMA Muhammadiyah 1 Palembang & 1,9 & 2,1 & 1,9 \\
\hline 3. & SMK Negeri 1 Palembang & 49,3 & 90,1 & 106,9 \\
\hline 4. & SMK PGRI 1 Palembang & 51,4 & 45,8 & 46,4 \\
\hline 5. & MA Negeri 1 Palembang & 4,4 & 5,1 & 5,5 \\
\hline \multicolumn{2}{|c|}{ Rata-rata } & 41,9 & 45,1 & 51,9 \\
\hline
\end{tabular}

Berdasarkan tabel di atas, dapat diketahui bahwa rata-rata rasio lancar pada koperasi tingkat SLTA di kota Palembang tahun 2014 sebesar 41,9 (4.190 persen) , tahun 2015 sebesar 45,1 (4.510 persen), dan tahun 2016 sebesar $\quad 51,9 \quad(5.190$ persen). Artinya untuk tahun 2014 saja jumlah aktiva lancar sebanyak 41,9 kali utang lancar, atau setiap 1 rupiah utang lancar dijamin oleh 41,9 rupiah harta lancar atau 41,9: 1 antara aktiva lancar dengan utang lancar. Demikian juga untuk tahun 2015 dan 2016, utang lancar lebih besar lagi dapat dijamin oleh aktiva lancar koperasi sekolah.

Dibandingkan dengan tahun 2015 dengan tahun 2014 rata-rata rasio lancar pada koperasi tingkat SLTA di kota Palembang mengalami kenaikan. Demikian juga jika dibandingkan antara tahun 2016 dan tahun 2015 rasio lancar mengalami kenaikan. Dengan demikian dapat disimpulkan bahwa rasio lancar pada koperasi sekolah tingkat SLTA di Kota Palembang dari tiga tahun terakhir lebih dari $250 \%$ sehingga dapat dikategorikan sehat. 


\section{b. Rasio Cepat}

TABEL 2 RASIO CEPAT LAPORAN KEUANGAN KOPERASI SEKOLAH

\begin{tabular}{|c|l|r|r|r|}
\hline No & \multicolumn{1}{|c|}{ Nama Sekolah } & Tahun 2014 & Tahun 2015 & Tahun 2016 \\
\hline 1. & SMA Negeri 19 Palembang & 100,9 & 82,5 & 98,5 \\
\hline 2. & SMA Muhammadiyah 1 Palembang & 1,8 & 1,9 & 1,9 \\
\hline 3. & SMK Negeri 1 Palembang & 40,6 & 76,8 & 88,8 \\
\hline 4. & SMK PGRI 1 Palembang & 51,4 & 45,8 & 46,4 \\
\hline 5. & MA Negeri 1 Palembang & 4,3 & 5,2 & 7,5 \\
\hline \multicolumn{2}{|c|}{ Rata-rata } & 39,8 & 42,4 & 48,6 \\
\hline
\end{tabular}

Berdasarkan tabel di atas, dapat diketahui bahwa rasio cepat pada koperasi tingkat SLTA di kota Palembang tahun 2014 sebesar 39,8 (3.980 persen), tahun 2015 sebesar 42,4 (4.240 persen), dan tahun 2016 sebesar 48,6 (4.860 persen). Dibandingkan dengan tahun 2015 dengan tahun 2014 rata-rata rasio cepat pada koperasi tingkat SLTA di kota Palembang mengalami kenaikan. Selanjutnya jika dibandingkan antara tahun 2016 dan tahun 2015 rasio cepat mengalami kenaikan. Dengan demikian dapat disimpulkan bahwa rasio cepat lancar pada koperasi sekolah tingkat SLTA di Kota Palembang dari tiga tahun terakhir masih dikategorikan sehat, mengingat rata-rata rasio cepat lebih dari $250 \%$.

Untuk kedua rasio di atas (rasio lancar dan rasio cepat), terlihat bahwa pada koperasi SMA Negeri 19 Palembang memiliki ratio yang sangat tinggi dan berbeda jauh dibanding koperasi sekolah lainnya. Berdasarkan hasil wawancara dengan ketua koperasi diketahui bahwa salah satu penyebabnya adalah karena koperasi sekolah selama beberapa tahun ini memang tidak memiliki utang. Hal itu sesuai dengan dokumentasi dari laporan keuangan koperasi yang ada, akun utang (baik utang jangka pendek maupun utang jangka panjang) tidak ada atau 0 (nol). 


\section{c. Rasio Kas atas Aktiva Lancar}

TABEL 3 RASIO KAS ATAS AKTIVA LANCAR LAPORAN KEUANGAN KOPERASI SEKOLAH

\begin{tabular}{|c|l|c|c|c|}
\hline No & \multicolumn{1}{|c|}{ Nama Sekolah } & Tahun 2014 & Tahun 2015 & Tahun 2016 \\
\hline 1. & SMA Negeri 19 Palembang & 2,3 & 2,7 & 3,3 \\
\hline 2. & SMA Muhammadiyah 1 Palembang & 16,3 & 14,7 & 20,9 \\
\hline 3. & SMK Negeri 1 Palembang & 3 & 3 & 4 \\
\hline 4. & SMK PGRI 1 Palembang & 61,3 & 59,8 & 35,8 \\
\hline 5. & MA Negeri 1 Palembang & 3,1 & 11,9 & 34,5 \\
\hline \multicolumn{2}{r|r|}{ Rata-rata } & 17,2 & 17,9 & 19,7 \\
\hline
\end{tabular}

Berdasarkan tabel di atas, dapat diketahui bahwa rasio rasio kas atas aktiva lancar pada koperasi tingkat SLTA di kota Palembang tahun 2014 sebesar $17,2 \quad(1.720$ persen), tahun 2015 sebesar 17,9 (1.790 persen), dan tahun 2016 sebesar 19,7 (1.970 persen). Dibandingkan dengan tahun 2015 dengan tahun 2014 rata-rata rasio lancar pada koperasi tingkat SLTA di kota Palembang mengalami kenaikan meskipun tidak terlalu tinggi. Sedangkan jika dibandingkan antara tahun 2016 dan tahun 2015 rasio lancar mengalami kenaikan yang sangat pesat. Dengan demikian dapat disimpulkan bahwa rasio kas atas aktiva lancar pada koperasi sekolah tingkat SLTA di Kota Palembang dari tiga tahun terakhir berangsur membaik sehingga dapat dikategorikan sehat.

\section{d. Rasio Kas atas Utang Lancar}

TABEL 4 RASIO KAS ATAS UTANG LANCAR LAPORAN KEUANGAN KOPERASI SEKOLAH

\begin{tabular}{|c|l|r|r|r|}
\hline No & \multicolumn{1}{|c|}{ Nama Sekolah } & Tahun 2014 & Tahun 2015 & Tahun 2016 \\
\hline 1. & SMA Negeri 19 Palembang & 2,3 & 2,8 & 3,2 \\
\hline 2. & SMA Muhammadiyah 1 Palembang & 32,2 & 31,2 & 39,2 \\
\hline 3. & SMK Negeri 1 Palembang & 161 & 240 & 432 \\
\hline 4. & SMK PGRI 1 Palembang & 31,5 & 27,4 & 16,6 \\
\hline 5. & MA Negeri 1 Palembang & 31,9 & 60,8 & 156,2 \\
\hline \multicolumn{2}{|l|}{ Rata-rata } & 51,8 & 72,4 & 129,4 \\
\hline
\end{tabular}

Berdasarkan tabel di atas, dapat diketahui bahwa rasio kas atas utang lancar pada koperasi tingkat SLTA di kota Palembang tahun 2014 
sebesar 51,8 (5.180 persen), tahun 2015 sebesar 72,4 (7.240 persen), dan tahun 2016 sebesar 129,4 (12.940 persen). Dibandingkan dengan tahun 2015 dengan tahun 2014 rata-rata rasio kas atas utang lancar pada koperasi tingkat SLTA di kota Palembang mengalami kenaikan. Sedangkan jika dibandingkan antara tahun 2016 dan tahun 2015 rasio rasio kas atas utang lancar juga mengalami kenaikan yang sangat drastis. Dengan demikian dapat disimpulkan bahwa rasio kas atas utang lancar pada koperasi sekolah tingkat SLTA di Kota Palembang dari tiga tahun terakhir dapat dikategorikan sehat.

\section{e. Rasio Aktiva Lancar dan Total Aktiva}

TABEL 5 RASIO AKTIVA LANCAR DAN TOTAL AKTIVA LAPORAN KEUANGAN KOPERASI SEKOLAH

\begin{tabular}{|c|l|r|r|r|}
\hline No & \multicolumn{1}{|c|}{ Nama Sekolah } & Tahun 2014 & Tahun 2015 & Tahun 2016 \\
\hline 1. & SMA Negeri 19 Palembang & 19,6 & 14,6 & 15,3 \\
\hline 2. & SMA Muhammadiyah 1 Palembang & 180,7 & 190 & 171 \\
\hline 3. & SMK Negeri 1 Palembang & 96 & 96 & 96 \\
\hline 4. & SMK PGRI 1 Palembang & 87,8 & 49,7 & 29,9 \\
\hline 5. & MA Negeri 1 Palembang & 441 & 508 & 548 \\
\hline Rata-rata & 165,02 & 171,66 & 172,04 \\
\hline
\end{tabular}

Berdasarkan tabel di atas, dapat diketahui bahwa rasio aktiva lancar dan total utang pada koperasi tingkat SLTA di kota Palembang tahun 2014 sebesar 165,02 (16.502 persen), tahun 2015 sebesar 171,66 (17.166 persen), dan tahun 2016 sebesar 172,04 (17.204 persen). Dibandingkan dengan tahun 2015 dengan tahun 2014 rata-rata rasio lancar pada koperasi tingkat SLTA di kota Palembang mengalami kenaikan. Sedangkan jika dibandingkan antara tahun 2016 dan tahun 2015 rasio aktiva lancar dan total utang juga mengalami kenaikan. Dengan demikian dapat disimpulkan bahwa rasio aktiva lancar dan total utang pada koperasi sekolah tingkat SLTA di Kota Palembang dari tiga tahun terakhir dapat dikategorikan sehat.

\section{Rasio Profitabilitas}

a. Margin Laba (Profit Margin) 
TABEL 6 RASIO MARGIN LABA LAPORAN KEUANGAN KOPERASI SEKOLAH

\begin{tabular}{|c|l|r|r|r|}
\hline No & Nama Sekolah & Tahun 2014 & Tahun 2015 & Tahun 2016 \\
\hline 1. & SMA Negeri 19 Palembang & 58 & 86,2 & 90,9 \\
\hline 2. & SMA Muhammadiyah 1 Palembang & 25 & 22 & 2,8 \\
\hline 3. & SMK Negeri 1 Palembang & 114 & 113 & 114 \\
\hline 4. & SMK PGRI 1 Palembang & 79,6 & 78,0 & 77,6 \\
\hline 5. & MA Negeri 1 Palembang & 29,1 & 65,4 & 43,1 \\
\hline \multicolumn{2}{|l}{ Rata-rata } & 61,1 & 72,9 & 65,7 \\
\hline
\end{tabular}

Berdasarkan tabel di atas, dapat diketahui bahwa margin laba (profit margin) pada koperasi tingkat SLTA di kota Palembang tahun 2014 rata-rata sebesar $61,1 \%$, tahun 2015 rata-rata sebesar $72,9 \%$, dan tahun 2016 rata-rata sebesar $65,7 \%$. Dibandingkan dengan tahun 2015 dengan tahun 2014 rata-rata margin laba (profit margin) pada koperasi tingkat SLTA di kota Palembang mengalami kenaikan. Sedangkan jika dibandingkan antara tahun 2016 dan tahun 2015 margin laba (profit margin) mengalami penurunan. Namun demikian dapat disimpulkan bahwa margin laba (profit margin) pada koperasi sekolah tingkat SLTA di Kota Palembang dari tiga tahun terakhir masih dapat dikategorikan sehat.

\section{b. Aset Turn Over}

TABEL 7 RASIO ASET TURN OVER LAPORAN KEUANGAN KOPERASI SEKOLAH

\begin{tabular}{|c|l|r|r|r|}
\hline No & \multicolumn{1}{|c|}{ Nama Sekolah } & Tahun 2014 & Tahun 2015 & Tahun 2016 \\
\hline 1. & SMA Negeri 19 Palembang & 0,34 & 0,17 & 0,17 \\
\hline 2. & SMA Muhammadiyah 1 Palembang & 0,11 & 0,44 & 0,22 \\
\hline 3. & SMK Negeri 1 Palembang & 0,73 & 0,79 & 0,7 \\
\hline 4. & SMK PGRI 1 Palembang & 0,57 & 0,64 & 0,62 \\
\hline 5. & MA Negeri 1 Palembang & 0,18 & 0,16 & 0,13 \\
\hline Rata-rata & 0,39 & 0,44 & 0,37 \\
\hline
\end{tabular}


Berdasarkan tabel di atas, dapat diketahui bahwa aset turn over pada koperasi tingkat SLTA di kota Palembang tahun 2014 rata-rata sebesar 0,39 (39 persen), tahun 2015 rata-rata sebesar 0,44 (44 persen), dan tahun 2016 rata-rata sebesar 0,37 (37 persen). Dibandingkan dengan tahun 2015 dengan tahun 2014 ratarata aset turn over pada koperasi tingkat SLTA di kota Palembang mengalami kenaikan. Sedangkan jika dibandingkan antara tahun 2016 dan tahun 2015 aset turn over mengalami penurunan. Namun demikian dapat disimpulkan bahwa aset turn over pada koperasi sekolah tingkat SLTA di Kota Palembang dari tiga tahun terakhir dapat dikategorikan sehat.

c. Return On Investment

TABEL 8 RASIO RETURN ON INVESTMENT LAPORAN KEUANGAN KOPERASI SEKOLAH

\begin{tabular}{|c|l|r|r|r|}
\hline No & Nama Sekolah & Tahun 2014 & Tahun 2015 & Tahun 2016 \\
\hline 1. & SMA Negeri 19 Palembang & 0,25 & 0,17 & 0,18 \\
\hline 2. & SMA Muhammadiyah 1 Palembang & 0,06 & 0,21 & 0,01 \\
\hline 3. & SMK Negeri 1 Palembang & 0,04 & 0,04 & 0,03 \\
\hline 4. & SMK PGRI 1 Palembang & 0,85 & 1,01 & 0,95 \\
\hline 5. & MA Negeri 1 Palembang & 0,05 & 0,10 & 0,07 \\
\hline \multicolumn{2}{|l|}{ Rata-rata } & 0,25 & 0,31 & 0,25 \\
\hline
\end{tabular}

Berdasarkan tabel di atas, dapat diketahui bahwa return on investment pada koperasi tingkat SLTA di kota Palembang tahun 2014 rata-rata sebesar 0,25 (25 persen), tahun 2015 rata-rata sebesar $0,31(31$ persen), dan tahun 2016 rata-rata sebesar $0,25 \quad$ (25 persen). Dibandingkan dengan tahun 2015 dengan tahun 2014 rata-rata return on investment pada koperasi tingkat SLTA di kota Palembang mengalami kenaikan. Sedangkan jika dibandingkan antara tahun 2016 dan tahun 2015 return on investment mengalami penurunan. Dengan demikian dapat disimpulkan bahwa rasio return on investment pada koperasi sekolah tingkat SLTA di Kota Palembang dari tiga tahun 
terakhir masih dapat dikategorikan

d. Return On Total Asset sehat.

TABEL 9 RASIO RETURN ON TOTAL ASSET LAPORAN KEUANGAN KOPERASI SEKOLAH

\begin{tabular}{|c|l|r|r|r|}
\hline No & \multicolumn{1}{|c|}{ Nama Sekolah } & Tahun 2014 & Tahun 2015 & Tahun 2016 \\
\hline 1. & SMA Negeri 19 Palembang & 0,20 & 0,15 & 0,15 \\
\hline 2. & SMA Muhammadiyah 1 Palembang & 0,03 & 0,20 & 0,01 \\
\hline 3. & SMK Negeri 1 Palembang & 0,04 & 0,03 & 0,03 \\
\hline 4. & SMK PGRI 1 Palembang & 0,46 & 0,5 & 0,49 \\
\hline 5. & MA Negeri 1 Palembang & 0,05 & 0,10 & 0,70 \\
\hline \multicolumn{2}{|l|}{ Rata-rata } & 0,16 & 0,18 & 0,27 \\
\hline
\end{tabular}

Berdasarkan tabel di atas, SIMPULAN DAN SARAN

dapat diketahui bahwa rasio return on total aset pada koperasi tingkat

\section{a. Simpulan}

Berdasarkan pembahasan yang SLTA di kota Palembang tahun 2014 rata-rata sebesar 0,16 (16 persen), tahun 2015 rata-rata sebesar $0,18(18$ persen), dan tahun 2016 rata-rata sebesar $0,27 \quad(27 \quad$ persen $)$. Dibandingkan dengan tahun 2015 dengan tahun 2014 rata-rata rasio lancar pada koperasi tingkat SLTA di kota Palembang mengalami kenaikan. Demikian juga jika dibandingkan antara tahun 2016 dan tahun 2015 rasio lancar mengalami kenaikan. Dengan demikian dapat disimpulkan bahwa rasio return on total aset pada koperasi sekolah tingkat SLTA di Kota Palembang dari tiga tahun terakhir dapat dikategorikan sehat. telah dijelaskan peneliti pada bab sebelumnya, maka dapat ditarik kesimpulan:

1) Rata-rata rasio lancar pada koperasi tingkat SLTA di kota Palembang tahun 2014 sebesar 41,9 (4.190 persen), tahun 2015 sebesar 45,1 (4.510 persen), dan tahun 2016 sebesar 51,9 (5.190 persen). Artinya untuk tahun 2014 saja jumlah aktiva lancar sebanyak 41,9 kali utang lancar, atau setiap 1 rupiah utang lancar dijamin oleh 41,9 rupiah harta lancar. Demikian juga untuk tahun 2015 dan 2016, utang lancar lebih besar lagi dapat dijamin oleh aktiva lancar koperasi sekolah. 
2) Margin laba (profit margin) pada koperasi tingkat SLTA di kota Palembang tahun 2014 rata-rata sebesar $61,1 \%$, tahun 2015 ratarata sebesar $72,9 \%$, dan tahun 2016 rata-rata sebesar $65,7 \%$.

Dapat disimpulkan bahwa margin laba (profit margin) pada koperasi sekolah tingkat SLTA di Kota Palembang dari tiga tahun terakhir masih dapat dikategorikan sehat.

\section{b. Saran}

Peneliti memberikan saran dan berharap saran ini dapat memberikan manfaat bagi semuanya, diantaranya sebagai berikut:.

1) Bagi sekolah, peneliti berharap bahwa pihak sekolah lebih memperhatikan aspek-aspek penunjang dalam mencipatkan laba yang besar bagi koperasi sekolah tersebut.

2) Bagi anggota koperasi, diharapkan dari perhitungan analisis rasio laporan keuangan ini dapat sebagai acuan untuk lebih giat lagi dalam keikutsertaan para anggota.
3) Bagi Peneliti selanjutnya, diharapkan dapat dijadikan sebagai referensi dalam pengambilan informasi dari penelitian yang sejenis di masa mendatang.

\section{DAFTAR PUSTAKA}

Arikunto, Suharsimi. 2010. Prosedur Penelitian Suatu Pendekatan Praktik. Jakarta: Rineka Cipta.

Astuty, Tri. 2015. Buku Pedoman Umum Pelajar Ekonomi. Jakarta: Vicasta Publisihing.

Gunawan, Imam. 2015. Metode Penelitian Kualitatif: Teori dan Praktik. Jakarta: Bumi Aksara.

Harahap, Sofyan Syafri. 2010. Analisis Kritis atas Laporan Keuangan. Jakarta: PT. Raja Grafindo Persada.

Hery. 2014. Analisis Laporan Keuangan. Cetakan Kedua. Jakarta: Bumi Aksara.

Jumingan. 2008. Analisis Laporan Keuangan. Cetakan Kedua. Jakarta: PT. Bumi Aksara.

Kasmir. 2015. Analisis Laporan Keuangan. Cetakan Kedelapan. Jakarta: Rajawali Pers.

Leksono, Sonny. 2013. Penelitian Kualitatif Ilmu Ekonomi dari Metodologi ke Metode. Jakarta: Rajawali Pers.

Munawir. 2010. Analisis Laporan Keuangan. Edisi Keempat. Yogyakarta: Liberty Yogyakarta.

Sugiyono. 2016. Metode Penelitian (Pendekatan Kuantitatif, Kualitatif, dan R\&D). Cetakan 
KeduaPuluh Tiga. Bandung: Alfabeta.

Surat Keputusan bersama antara Departemen Transmigrasi dan Koperasi dengan Departemen Pendidikan dan Kebudayaan Tanggal 16 Juli 1972 Nomor 275/KPTS/Mentranskop dan Nomor 0102/U/1983 tentang koperasi sekolah

Surat Keputusan Menteri Tenaga Kerja, Transmigrasi, dan Koperasi Nomor 633/SKPTS/Men/1974 tentang koperasi sekolah

Undang-Undang Dasar Republik Indonesia Tahun 1945. 2106. Jakarta : Pustaka

Undang-Undang Republik Indonesia Nomor 25 Tahun 1992 tentang Perkoperasian

Undang-Undang Republik Indonesia Nomor 17 Tahun 2012 tentang Perkoperasian

Wikipedia. 2013. Koperasi Sekolah (Online)

https://id.wikipedia.org/wiki/Ko perasi sekolah di akses jam $\underline{21.50}$ WIB Tanggal 02 Februari 2017. 